\title{
Lipase Catalysed Ethanolysis of Jatropha Oil for Biodiesel Production
}

\author{
Elizabeth Funmilayo Aransiola ${ }^{1}$ \\ ${ }^{1}$ Department of Chemical Engineering, Obafemi Awolowo University, Ile-Ife, Nigeria \\ Correspondence: Elizabeth Funmilayo Aransiola, Department of Chemical Engineering, Obafemi Awolowo \\ University, Ile-Ife, Nigeria. Tel: 234-803-953-7535. E-mail: aransiola4@yahoo.com \& aransiolaef@gmail.com
}

\author{
Received: March 11, 2013 Accepted: April 6, 2013 Online Published: April 19, 2013 \\ doi:10.5539/eer.v3n1p85 URL: http://dx.doi.org/10.5539/eer.v3n1p85
}

\begin{abstract}
This study investigated ethanolysis of both crude and pre-treated Jatropha oil using immobilized lipase from Pseudomonas cepacia. The methods employed were stepwise addition of ethanol and n-hexane as solvent. The ethanol was added three times in a stepwise way so as to prevent enzyme inhibition. The effects of reaction temperature and oil to ethanol ratio were studied. Maximum yields of fatty acid ethyl ester (FAEE) of $66.7 \mathrm{wt} \%$, $72.1 \mathrm{wt} \%$ and $58.8 \mathrm{wt} \%$ were obtained at oil to ethanol ratio of $1: 4$ for crude Jatropha curcas oil at reaction temperatures of 30,40 , and $50{ }^{\circ} \mathrm{C}$ respectively. Each run of the experiment took an overall reaction period of 48 h. These results showed the best optimized reaction temperature to be $40{ }^{\circ} \mathrm{C}$. A maximum FAEE yield of 96.1 wt $\%$ was obtained when pre-treated Jatropha curcas oil was transesterified at the best optimized conditions. The loss noticed after 13 cycles in the activity of the enzyme was quite negligible. This proved it to be a stable one. The physical properties of the biodiesel obtained from the pre-treated Jatropha oil met the ASTM standard of D-6751.
\end{abstract}

Keywords: biodiesel, ethanolysis, Jatropha oil, lipase enzyme

\section{Introduction}

The energy trend of our present generation is fast moving towards a renewable one due to high diminishing rate of fossil fuels, its environmental problems and increasing prices of crude oil. Biodiesel, a form of biofuel is being intensively researched to as a solution to the problems generated by fossil fuel.

Recently, much attention is being paid on it as green, non toxic, environmentally safe and renewable fuel (Yucel, 2011). The major feedstocks for biodiesel production are edible, non-edible, used vegetable oils and animal fats. Edible oils' utilization for production of biodiesel is being disannulled as it is highly competitive with consumption; hence attention is being shifted to non-edible and waste or used vegetable oils (E. F. Aransiola, Betiku, Ikhuomoregbe, \& Ojumu, 2012; E. F. Aransiola, Ojumu, Oyekola, \& Ikhuomoregbe, 2012; Jain \& Sharma, 2010; Tsai, Lin, \& Yeh, 2007; R. Wang et al., 2011). In this study, a non-edible oil known as Jatropha curcas oil was used.

Jatropha curcas L. also known as physic nut is from Euphorbiaceous family. The seeds are very rich in oil (30 to $50 \%$ by weight of the seed) (Pramanik, 2003). It is a plant that grows on prolonged period of abnormally low rainfall and also on unused land. These characteristics make it uncompetitive with food crops. The toxicity of the seeds and the oil is as a result of the phorbol esters present in them (Kumari, Mahapatra, Garlapati, \& Banerjee, 2009). Jatropha curcas oil has $21.6 \%, 45.4 \%$ and $33 \%$ of saturated, monounsaturated and polyunsaturated fatty acids (Akbar, Yaakob, Kamarudin, Ismail, \& Salimon, 2009; E. F. Aransiola et al., 2012). The most suitable vegetable oil for producing biodiesel must be readily available, its plant should be easy to cultivate and its composition must include a high percentage of monounsaturated fatty acids when compared relatively to other fatty acids (R. Wang et al., 2011). Based on these criteria, Jatropha curcas oil is potentially seen as a useful renewable feedstock for biodiesel production.

The common methods used in producing this biodiesel (fatty acid alkyl esters) are acid and alkali methods of catalysis. These methods have some problems associated with it: downstream processing costs, by-products recovery and environmental problems. Al-Zuhair et al. (2007) also reviewed other drawbacks associated with the chemical catalyst as being energy intensive, unwanted side products generated from the use of alkali catalyst especially in the presence of free fatty acids in the oil, hence the need to search for better and alternative methods of production. Enzyme method of catalysis can act as a substitute to the chemical ones due to these 
characteristics attached to it; its reusability, specificity, ability to accept new substrates, thermo stability, mild reaction conditions in terms of low temperature and its environmental friendliness (Akoh, Chang, Lee, \& Shaw, 2007; Al-Zuhair et al., 2007; Modi, Reddy, Rao, \& Prasad, 2007; Noureddini, Gao, \& Philkana, 2005; Ognjanovic, Bezbradica, \& Knezevic-Jugovic, 2009). These characteristics have factored the reactions with the use of enzyme to be termed green (Akoh et al., 2007).

Enzymes are used for transesterification reaction, though not commercially developed. As reviewed by Akoh et al. (2007), recent awareness is on the use of lipase as a biocatalyst for fatty acid methyl ester production. This is because it is economically feasible in terms of energy consumption, and also due to its high efficiency and selectivity.

Some researchers had revealed enzyme to be a promising catalyst and in order to establish its use industrially, the reaction conditions (temperature, oil/alcohol molar ratio, amount of enzyme used, reaction time) need to be optimized (Akoh et al., 2007; Modi et al., 2007; Moreira, Perez, Zanin, \& de Castro, 2007; Noureddini et al., 2005; Shah \& Gupta, 2007; Shah, Sharma, \& Gupta, 2004; Wang, Liu, Zhao, Ding, \& Xu, 2011; Yucel, 2011).

When synthesizing biodiesel using lipase enzyme, the high cost and inactivation by methanol are considered its major limitations. The problem of high cost can be solved to a greater extent by employing the process of immobilization and genetically engineering them. The issue of inhibition by methanol makes the type of alcohol for enzyme transesterification an important factor for consideration. Another type of alcohol that can be considered is ethanol; it is readily available and cheaper. A lot of studies had been conducted by using these two types of alcohol. Triolein's transesterification with methanol and ethanol using lipase from P.cepacia was investigated by Salis et al (2005), and a conversion of $38 \%$ and $90 \%$ were obtained respectively. Noureddini et al. (2005) also reported $67 \%$ conversion when soybean oil was transesterified with methanol using lipase from P.cepacia. Abigor et al. (2000) investigated the conversion of palm kernel oil using ethanol and methanol and P. cepacia as a lipase and conversions of $72 \%$ and $15 \%$ were attained respectively. Although lipase deactivation was reported due to contact between alcohol and the enzyme (Shimada, Watanabe, Sugihara, \& Tominaga, 2002), this was minimized by stepwise addition of the alcohol in 2 or 3 steps (Shimada et al., 1999; Watanabe et al., 2000). From all the findings above, ethanol is seen as a better alcohol for enzyme catalyzed reaction, as it can also be synthesized from non toxic renewable biomass categorized as wastes, such as molasses, cassava bagasse, sawdust, banana peels. Comparing ethanol with methanol from economical point of view, ethanol is a cheaper substrate for biodiesel production as it can be produced from cheaper and readily available sources. The biodiesel produced when ethanol is used as alcohol and enzyme used as catalyst in conjunction with non edible oil makes it a total $(100 \%)$ green product. This study is therefore aimed at producing biodiesel by ethanolysis of non edible oil; Jatropha curcas oil using immobilized lipase enzyme from Pseudomonas cepacia.

\section{Materials and Methods}

\subsection{Materials}

The acquirement of the Jatropha seeds was done from a town in Nigeria called Ikere-Ekiti. Analytical grade chemicals used were Ethanol, Acetone, Lipase immobilized in Sol-Gel-Ak from Pseudomonas cepacia 40U/g, Oleic acid, 1-Oleoyl rac-glycerol, 1, 2 Dioleyol-rac-glycerol, Triolein, Oleic acid ethyl oleate, Acetonitrile and nHexane. These were purchased from Sigma Aldrich in Germany.

\subsection{Experimental Set up}

\subsubsection{Pretreatment of the Crude Oil}

Akintayo (2004) method was employed in extracting the oil from the Jatropha seed. The free fatty acid was tested and discovered very high. The method used for the pretreatment was that of Berchmans and Hirata (2008). The pretreatment was carried out via acid esterification process in order to decrease the FFA content. Methanol and sulphuric acid were mixed together and warmed for 15 minutes. The quantity of methanol and sulphuric acid added slowly to the oil were $60 \% \mathrm{w} / \mathrm{w}$ and $1 \% \mathrm{w} / \mathrm{w}$ of oil respectively. These were allowed to agitate for one hour at $60{ }^{\circ} \mathrm{C}-65^{\circ} \mathrm{C}$. Afterwards, the mixture got settled and the top layer having the majority of the FFA was separated leaving the bottom layer which is the pretreated oil. The FFA of the pretreated oil was further tested.

\subsubsection{Enzymatic Catalysis of Jatropha curcas Oil}

Batch transesterification of crude Jatropha curcas oil was performed in an Erlenmeyer flask of $250 \mathrm{ml}$ containing 11.2 gram of the oil. These were carried out in an incubator shaker at different temperatures and reaction periods of $30{ }^{\circ} \mathrm{C}, 40^{\circ} \mathrm{C}$ and $50{ }^{\circ} \mathrm{C}$ and $6 \mathrm{~h}, 12 \mathrm{~h}, 24 \mathrm{~h}$ and $48 \mathrm{~h}$ respectively. The reaction mixtures were done at oil to ethanol molar ratios of 1:3, 1:4 and 1:6 using the 3-stepwise method of reaction. One third molar of the required ethanol was added every one third hour of the reaction time. To the reaction mixture, $4 \mathrm{wt} \%$ of the 
immobilized enzyme was added and also $0.6 \mathrm{ml}$ of hexane in enhancing its solubility. The addition of hexane and the enzyme had been done before adding the first one third molar of the alcohol added. The agitation rate was kept constant at $200 \mathrm{rpm}$.

On completion of the various experimental runs, the product was centrifuged in order to separate the upper layer which is the ethyl ester. This ester with other glycerides was analyzed for the different parameters required. The enzyme was washed with hexane and reused for the next experiment. Based on the optimal conditions obtained when the ethyl ester from transesterification of crude Jatropha curcas oil was analyzed, this was used for the pre-treated Jatropha curcas oil.

The experiment was scaled up in order to be able to get enough biodiesel samples for characterization according to the American Standard Testing Method.

\subsubsection{The Immobilized Enzyme's Performance}

In order to determine the ability or performance of an immobilized enzyme, its stability must be significantly considered. (Kumari et al., 2009). Factors like too much alcohol and glycerol do have a negative effect on the activity of the enzyme. This is due to hydrophilic and insolubility nature of glycerol in the oil giving room for adsorption on the surface of the enzyme. The reduced life span of the enzyme is also associated with excess alcohol (Dizge \& Keskinler, 2008).

At the end of every experimental run, the immobilized enzyme was rinsed with n-hexane so as to remove the glycerol attached to it. The stepwise adding of ethanol was adopted in order to avoid enzyme inhibition. The relative activity of the enzyme after 13 cycles was seen relative to the yield of the FAEE obtained.

\subsection{Analytical Methods}

\subsubsection{Percentage Oil Yield and Its Physico-Chemical Analysis}

The analysis on the oil; its percentage oil yield and physicochemical properties (saponification and acid values) had been carried out in some of our previous studies (E. F. Aransiola et al., 2012; E. Aransiola, et al., 2012).

\subsubsection{Ester and Glyceride Analysis by HPLC Method}

LC - 20AB HPLC connected to an ultraviolet detector consisting of a controller, auto sampler and binary pump was used in measuring the concentration of the ester produced, as well as the other glycerides present. The standards used were 1-oleoyl rac-glycerol, 1, 2 dioleyol-rac-glycerol, triolein and ethyl oleate. The mobile phases are Acetone and Acetonitrile at ratio of 49 to 51 at a flow rate of 0.7 Ml.min-1. The column used was $4.6 \mathrm{~mm}$ ID x $15 \mathrm{~cm}$ CLC-ODS (T) of $5 \mu \mathrm{m}$ particles and $100 \AA$ pore size. The preparation of the samples and analysis were done according to Aransiola (2012), Dubé et al. (2004) and Darnoko and Cheryan (2000).

\subsubsection{Biodiesel Characterization}

The methods employed in characterizing the biodiesel produced was according to our previous study Aransiola et al. (2010).

Table 1. Jatropha Biodiesel Characteristics and Biodiesel Standards

\begin{tabular}{llll}
\hline Properties & Jatropha Biodiesel & Biodiesel Standard ASTM 6751 & Test Method \\
\hline Flash point $\left({ }^{\circ} \mathrm{C}\right)$ & Not determined & $130(\mathrm{~min})$ & ASTMD -93 \\
Moisture content & Nil & $0.050 \mathrm{max}$ & ASTMD -2709 \\
Kinematic viscosity $\left(\mathrm{mm}^{2} / \mathrm{s}\right)$ & 5.6 & 1.9 t0 6.0 & ASTMD -445 \\
Cloud Point $\left({ }^{\circ} \mathrm{C}\right)$ & 3 & - & ASTMD -2500 \\
Specific gravity at $15 / 15^{\circ} \mathrm{C}$ & 0.88 & 0.860 to 0.900 & - \\
Pour point $\left({ }^{\circ} \mathrm{C}\right)$ & -3 & -15 to 10 & ASTMD -97 \\
\hline
\end{tabular}

*These are mean values of data measured in duplicates. 


\section{Results and Discussions}

\subsection{The Physico-Chemical Properties of the Jatropha curcas Oil}

The physico-chemical properties of the oil are shown in Table 2. This is quite comparable to the results revealed by Akintayo (2004).

The percentage oil content obtained was approximately 52\% comparable to the ones obtained by Akintayo (2004), Martín et al. (2010) and Akbar et al. (2009) respectively. This high percentage of the oil and its high content of monounsaturated value are the indicative measures that it is quite suitable as a substrate for biodiesel production.

The percentage free fatty acid values of the crude and pre-treated oil were $18.1 \%$ and $0.6 \%$ respectively.

Table 2. The Physico-chemical properties of Jatropha curcas oil

\begin{tabular}{ll}
\hline Parameters & Values \\
\hline Acid value $\left(\mathrm{mgKOH} . \mathrm{g}^{-1}\right)$ & 35.8 \\
Percentage oil yield (\%) & 52.2 \\
Density at room temperature $\left(\mathrm{kg} . \mathrm{m}^{-3}\right)$ & 895 \\
Viscosity at room temperature $(\mathrm{cSt})$ & 41.4 \\
Saponification value (mgKOH.g $\left.\mathrm{g}^{-1}\right)$ & 193 \\
Free fatty acid of crude oil $(\%)$ & 18.1 \\
Free fatty acid of pre-treated oil (\%) & 0.6 \\
\hline
\end{tabular}

These are mean values of data measured in duplicates.

\subsection{Enzyme Catalysis of Jatropha curcas Oil to Biodiesel}

The alcohol-to-oil ratio and reaction temperature effects were studied for enzyme catalysis of crude and pre-treated Jatropha curcas oil for biodiesel production. Stirring speed of all experiments was fixed at $200 \mathrm{rpm}$.

\subsubsection{Effect of Oil to Alcohol Molar Ratio}

Figures 1 depict the oil-to-alcohol ratio effect on the biodiesel at $30{ }^{\circ} \mathrm{C}$ (Figure 1A), $40{ }^{\circ} \mathrm{C}$ (Figure 1B), and 50 ${ }^{\circ} \mathrm{C}$ (Figure 1C). In all these temperatures, ester concentration increases from oil to alcohol molar ratio of 1:3 to $1: 4$ but decreases at a ratio of 1:6. This may be due to the excess ethanol inhibiting the enzyme and thus reducing its percentage conversion to ester. The three stepwise reactions are carried out so as not to allow the excess alcohol to inhibit the enzyme For the oil to ethanol of 1:6, two times of what was supposed to be introduced per one-third of the stoichiometric ratio was used for the reaction which may really be the cause of the low fatty acid ethyl ester concentration produced. The best results of $66.7 \mathrm{wt} \%, 72.1 \mathrm{wt} \%$ and $58.8 \mathrm{wt} \%$ were obtained for temperatures of 30,40 , and $50{ }^{\circ} \mathrm{C}$ respectively at oil to ethanol ratio of $1: 4$. Typical compositions profiles of TG, DG, MG and Fatty Acid Ethyl ester for the enzyme catalysis of the crude Jatropha oil at the temperatures of 30, 40, and $50{ }^{\circ} \mathrm{C}$ for oil to ethanol ratio of $1: 4$ are shown in Figures 2A-C. The yields are not so high and this was attributed to the presence the phospholids and free fatty acid in the oil. This led to the use of pre-treated Jatropha curcas oil which was transesterified by using the lipase enzyme at the best condition obtained for the above results. Surprisingly, it gave a very good yield of $96.1 \mathrm{wt} \%$. This is shown in Figure 3.

\subsubsection{Effect of Reaction Temperature}

The use of enzymes is very sensitive to temperature effects. This temperature effect against the best oil to alcohol ratio (1:4) for crude Jatropha oil is shown in Figure 4. In this figure, temperature of $40{ }^{\circ} \mathrm{C}$ gave a best result of $72.1 \mathrm{wt} \%$. The pre-treated oil gave a yield of $96.1 \mathrm{wt} \%$ at the same reaction temperature (Figure 3). This agrees with the study conducted by Shimada et al (2002) and Dizge and Keskinler (2008) who confirmed that lipase enzyme operates best between temperatures of $30^{\circ} \mathrm{C}$ and $40{ }^{\circ} \mathrm{C}$. 

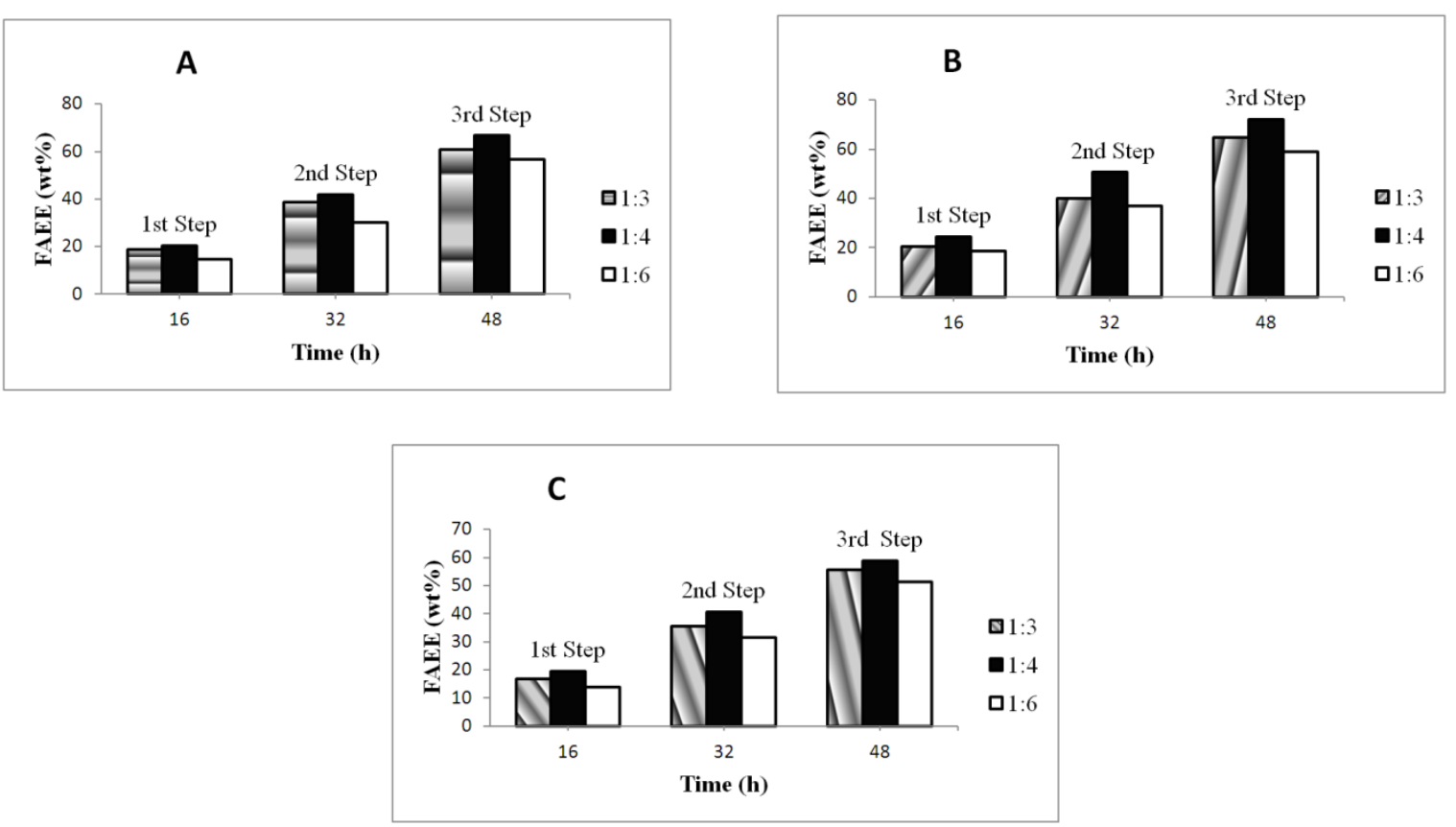

Figure 1. Results of oil-to-ethanol molar ratio on FAEE concentration for crude Jatropha curcas oil using immobilized Lipase from Pseudomonas cepacia for $48 \mathrm{~h}$. A. at $30{ }^{\circ} \mathrm{C}$; B. at $40{ }^{\circ} \mathrm{C}$ and C. at $50{ }^{\circ} \mathrm{C}$
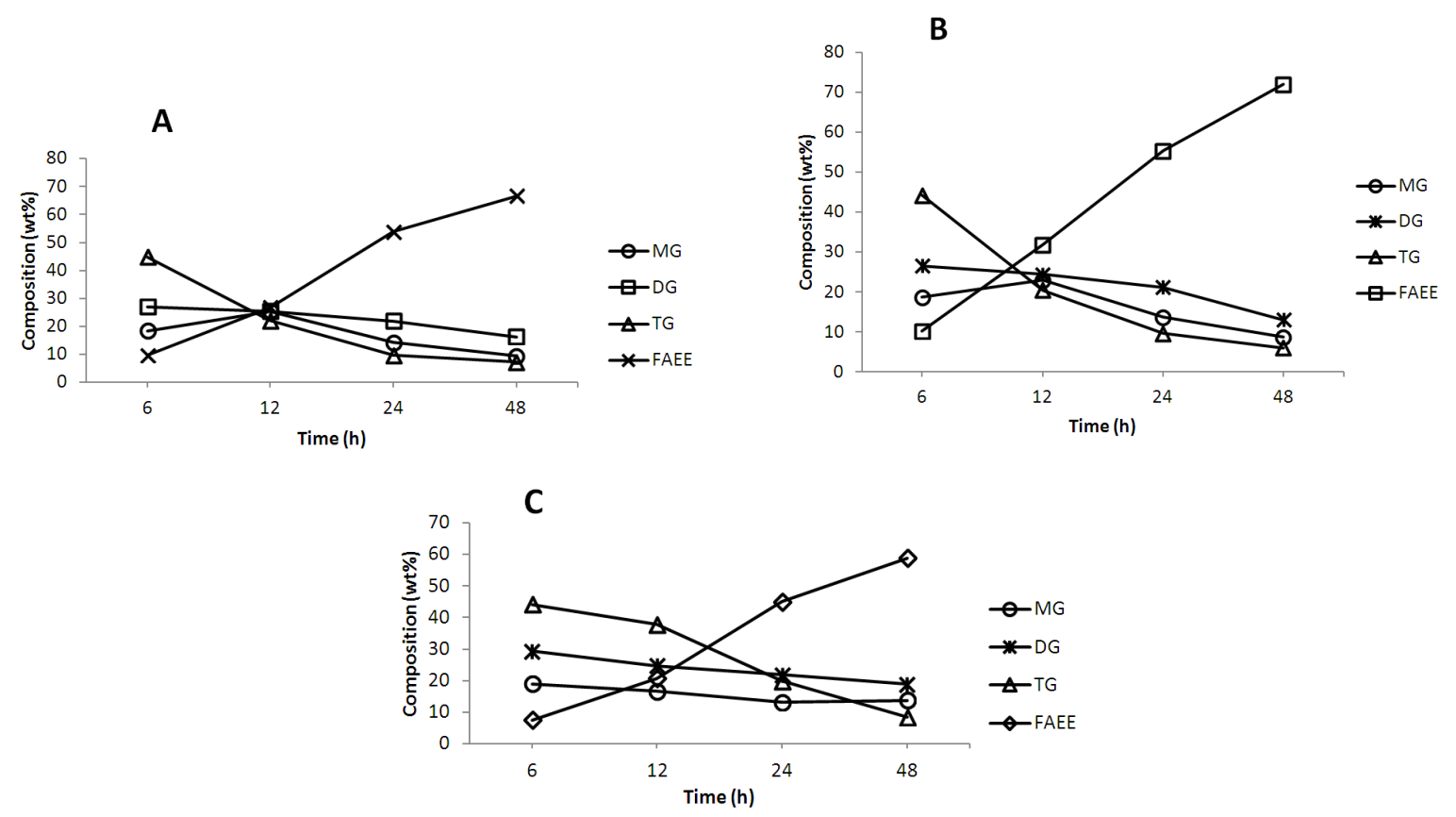

Figure 2. Composition of product obtained by three step flow ethanolysis of Crude Jatropha by Lipase from Pseudomonas cepacia at different reaction periods for oil to ethanol ratio of $1: 4$. A. at $30^{\circ} \mathrm{C} ; \mathbf{B}$. at $40{ }^{\circ} \mathrm{C}$ and $\mathbf{C}$. at $50{ }^{\circ} \mathrm{C}$ 


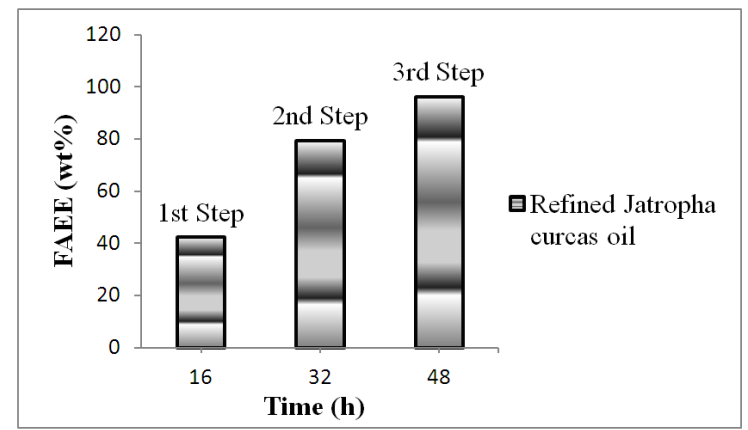

Figure 3. Three Stepwise Ethanolysis of Pre-treated Jatropha curcas Oil at $40{ }^{\circ} \mathrm{C}$ for $48 \mathrm{~h}$ using immobilized Lipase from Pseudomonas cepacia for oil to alcohol ratio of 1:4

A

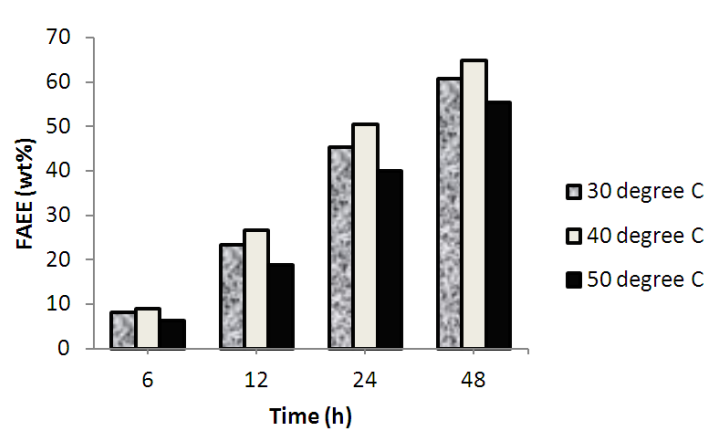

C

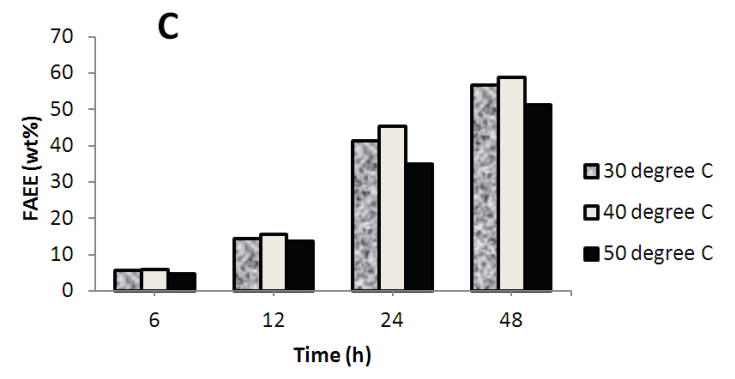

B

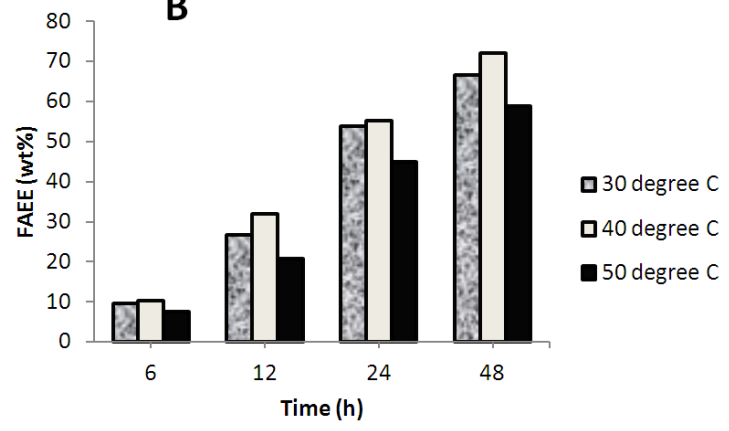

Figure 4. Effect of temperature on FAEE concentration against reaction time for crude Jatropha curcas oil using immobilized Lipase from Pseudomonas cepacia. A. oil-to-ethanol molar ratio of 1:3; B. oil-to-ethanol molar ratio of 1:4; C. oil-to-ethanol molar ratio of $1: 6$

\subsection{The Immobilized Enzyme's Performance}

The relative activity of the enzyme after 13 cycles was seen relative to the yield of the FAEE obtained. FAEE yield of $96.1 \mathrm{wt} \%$ was obtained at the $13^{\text {th }}$ cycle after transesterification of the pre-treated Jatropha oil. This was a good evidence of the operational stability of the enzyme. This high yield and lipase stability after several uses may have resulted as a result of the hexane in the reaction, which notably lowered the adsorption of the glycerol on the enzyme.

\subsection{Characteristics of the Biodiesel Obtained}

The characteristics of the biodiesel obtained from the Nigerian Jatropha curcas oil, as well as its standard are presented in Table 1. It is noteworthy that the characteristics of the biodiesel produced were quite comparable with the standard.

\section{Conclusion}

This study presents the ethanolysis of both crude and pre-treated Jatropha curcas oil using immobilized lipase enzyme from Pseudomonas cepacia. The solvent used was n-hexane and ethanol was added stepwisely so as to hinder enzyme inhibition. The effects of oil-to-ethanol molar ratio and reaction temperature on the ester yield were studied. Maximum FAEE yields of $72.1 \%$ and $96.1 \%$ were obtained from ethanolysis of the crude and 
pre-treated Jatropha curcas oil at optimized conditions (Reaction temperature of $40{ }^{\circ} \mathrm{C}$, oil to ethanol ratio of 1:4 and reaction period of $48 \mathrm{~h}$ ). The use of ethanol is seen as a better alcohol for enzyme catalyzed reaction, as it can be synthesized from renewable sources and also cheaper when compared to methanol. The excellent performance of the enzyme is an indication that if the process is embarked upon, the potential to be efficient is high. This study therefore reveals that ethanolysis of non edible oil; Jatropha curcas oil using a stable immobilized lipase enzyme could lead to a green product; biodiesel. The results reported will serve as a motivation for other researchers involved in biodiesel production in not neglecting the use of enzyme as catalysts as it gives high yield and a green product. This study also has the potential to be economically feasible if the continuous process is embarked upon.

\section{Acknowledgements}

I will like to acknowledge the financial assistance rendered by the Education Trust Fund in Nigeria. Big thanks also to National Research Institute of Chemical Technology, Zaria for giving me the working space to analyse my work.

\section{References}

Abigor, R. D., Uadia, P. O., Foglia, T. A., Haas, M. J., Jones, K. C., Okpefa, E., ... Bafor, M. E. (2000). Lipase-catalysed production of biodiesel fuel from some Nigerian lauric oils. Biochemical Society Transactions, 28(6), 979-982. http://dx.doi.org/10.1042/0300-5127:0280979

Akbar, E., Yaakob, Z., Kamarudin, S. K., Ismail, M., \& Salimon, J. (2009). Characteristic and composition of Jatropha curcas oil seed from Malaysia and its potential as biodiesel feedstock feedstock. European Journal of Scientific Research, 29(3), 396-403.

Akintayo, E. T. (2004). Characteristics and composition of Parkia biglobbossa and Jatropha curcas oils and cakes. Bioresource Technology, 92(3), 307-310. http://dx.doi.org/10.1016/S0960-8524(03)00197-4

Akoh, C. C., Chang, S. W., Lee, G. C., \& Shaw, J. F. (2007). Enzymatic approach to biodiesel production. Journal of Agricultural and Food Chemistry, 55(22), 8995-9005. http://dx.doi.org/10.1021/jf071724y

Al-Zuhair, S., Ling, F. W., \& Jun, L. S. (2007). Proposed kinetic mechanism of the production of biodiesel from palm oil using lipase. Process Biochemistry, 42(6), 951-960. http://dx.doi.org/10.1016/j.procbio.2007.03.002

Aransiola, E., Betiku, E., Layokun, S., \& Solomon, B. (2010). Production of biodiesel by transesterification of refined soybean oil. International Journal of Biological and Chemical Sciences, 4(2), 391-399.

Aransiola, E. F., Daramola, M. O., Ojumu, T. V., Aremu, M. O., Layokun, S. K., \& Solomon, B. O. (2012). Nigerian Jatropha Curcas Oil Seeds: Prospect for Biodiesel Production in Nigeria. International Journal of Renewable Energy Research (IJRER), 2(2), 317-325.

Aransiola, E. F., Betiku, E., Ikhuomoregbe, D. I. O., \& Ojumu, T. V. (2012). Production of biodiesel from crude neem oil feedstock and its emissions from internal combustion engines. Afr. J. Biotechnol, 11(22), 6178-6186. http://dx.doi.org/10.5897/AJB11.2301

Aransiola, E. F., Ojumu, T. V., Oyekola, O. O., \& Ikhuomoregbe, D. I. O. (2012). A Study of Biodiesel Production from Non-Edible Oil Seeds: A Comparative Study. The Open Conference Proceedings Journal, $3,18-22$.

Berchmans, H. J., \& Hirata, S. (2008). Biodiesel production from crude Jatropha curcas L. seed oil with a high content of free fatty acids. Bioresource Technology, 99(6), 1716-1721. http://dx.doi.org/10.1016/j.biortech.2007.03.051

Darnoko, D., \& Cheryan, M. (2000). Kinetics of palm oil transesterification in a batch reactor. Journal of the American Oil Chemists' Society, 77(12), 1263-1267. http://dx.doi.org/10.1007/s11746-000-0198-y

Dizge, N., \& Keskinler, B. (2008). Enzymatic production of biodiesel from canola oil using immobilized lipase. Biomass and Bioenergy, 32(12), 1274-1278. http://dx.doi.org/10.1016/j.biombioe.2008.03.005

Dubé, M. A., Zheng, S., McLean, D. D., \& Kates, M. (2004). A comparison of attenuated total reflectance-FTIR spectroscopy and GPC for monitoring biodiesel production. Journal of the American Oil Chemists' Society, 81(6), 599-603. http://dx.doi.org/10.1007/s11746-006-0948-x

Jain, S., \& Sharma, M. P. (2010). Prospects of biodiesel from Jatropha in India: A review. Renewable and Sustainable Energy Reviews, 14(2), 763-771. http://dx.doi.org/10.1016/j.rser.2009.10.005 
Kumari, A., Mahapatra, P., Garlapati, V.K ., \& Banerjee, R. (2009). Enzymatic transesterification of Jatropha oil. Biotechnol Biofuels, 2(1), 1-6. http://dx.doi.org/10.1186/1754-6834-2-1

Martín, C., Moure, A., Martín, G., Carrillo, E., Domínguez, H., \& Parajó, J. C. (2010). Fractional characterisation of jatropha, neem, moringa, trisperma, castor and candlenut seeds as potential feedstocks for biodiesel production in Cuba. Biomass and Bioenergy, 34(4), 533-538. http://dx.doi.org/10.1016/j.biombioe.2009.12.019

Modi, M. K., Reddy, J. R. C., Rao, B. V. S. K., \& Prasad, R. B. N. (2007). Lipase-mediated conversion of vegetable oils into biodiesel using ethyl acetate as acyl acceptor. Bioresource Technology, 98(6), 1260-1264. http://dx.doi.org/10.1016/j.biortech.2006.05.006

Moreira, A. B. R., Perez, V. H., Zanin, G. M., \& de Castro, H. F. (2007). Biodiesel synthesis by enzymatic transesterification of palm oil with ethanol using lipases from several sources immobilized on silica-PVA composite. Energy \& Fuels, 21(6), 3689-3694. http://dx.doi.org/10.1021/ef700399b

Noureddini, H., Gao, X., \& Philkana, R. S. (2005). Immobilized Pseudomonas cepacia lipase for biodiesel fuel $\begin{array}{lllll}\text { production from soybean oil. Bioresource Technology, 96(7), } & \text { 769-777. }\end{array}$ http://dx.doi.org/10.1016/j.biortech.2004.05.029

Ognjanovic, N., Bezbradica, D., \& Knezevic-Jugovic, Z. (2009). Enzymatic conversion of sunflower oil to biodiesel in a solvent-free system: process optimization and the immobilized system stability. Bioresource Technology, 100(21), 5146-5154. http://dx.doi.org/10.1016/j.biortech.2009.05.068

Salis, A., Pinna, M., Monduzzi, M., \& Solinas, V. (2005). Biodiesel production from triolein and short chain alcohols through biocatalysis. Journal of Biotechnology, 119(3), 291-299. http://dx.doi.org/10.1016/j.jbiotec.2005.04.009

Shah, S., \& Gupta, M. N. (2007). Lipase catalyzed preparation of biodiesel from Jatropha oil in a solvent free system. Process Biochemistry, 42(3), 409-414. http://dx.doi.org/10.1016/j.procbio.2006.09.024

Shah, S., Sharma, S., \& Gupta, M. N. (2004). Biodiesel preparation by lipase-catalyzed transesterification of Jatropha oil. Energy \& Fuels, 18(1), 154-159.

Shimada, Y., Watanabe, Y., Samukawa, T., Sugihara, A., Noda, H., Fukuda, H., \& Tominaga, Y. (1999). Conversion of vegetable oil to biodiesel using immobilized Candida antarctica lipase. Journal of the American Oil Chemists' Society, 76(7), 789-793. http://dx.doi.org/10.1007/s11746-999-0067-6

Shimada, Y., Watanabe, Y., Sugihara, A., \& Tominaga, Y. (2002). Enzymatic alcoholysis for biodiesel fuel production and application of the reaction to oil processing. Journal of Molecular Catalysis B: Enzymatic, 17(3), 133-142. http://dx.doi.org/10.1016/S1381-1177(02)00020-6

Tsai, W. T., Lin, C. C., \& Yeh, C. W. (2007). An analysis of biodiesel fuel from waste edible oil in Taiwan. Renewable and Sustainable Energy Reviews, 11(5), 838-857. http://dx.doi.org/10.1016/j.rser.2005.05.005

Wang, R., Hanna, M. A., Zhou, W. W., Bhadury, P. S., Chen, Q., Song, B. A., \& Yang, S. (2011). Production and selected fuel properties of biodiesel from promising non-edible oils: Euphorbia lathyris L., Sapium sebiferum L. and Jatropha curcas L. Bioresource Technology, 102(2), 1194-1199. 10.1016/j.biortech.2010.09.066

Wang, X., Liu, X., Zhao, C., Ding, Y., \& Xu, P. (2011). Biodiesel production in packed-bed reactors using lipase-nanoparticle biocomposite. Bioresource Technology, 102(10), 6352-6355. http://dx.doi.org/10.1016/j.biortech.2011.03.003

Watanabe, Y., Shimada, Y., Sugihara, A., Noda, H., Fukuda, H., \& Tominaga, Y. (2000). Continuous production of biodiesel fuel from vegetable oil using immobilized Candida antarctica lipase. Journal of the American Oil Chemists' Society, 77(4), 355-360. http://dx.doi.org/10.1007/s11746-000-0058-9

Yucel, Y. (2011). Biodiesel production from pomace oil by using lipase immobilized onto olive pomace. Bioresource Technology, 102(4), 3977-3980. http://dx.doi.org/10.1016/j.biortech.2010.12.001 